\title{
Student Opinions on Efficacy-Based Learning Approach in Science and Technology Teaching: A Phenomenological Study*
}

\author{
Mustafa YEŞILYURT ${ }^{1}$, Mustafa EROL ${ }^{2}$
}

Received: 05/10/2018| Accepted: 03/01/2019| Published: 15/01/2019

\begin{abstract}
The aim of the study is to examine the thoughts of teacher candidates on Science and Technology Teaching based on effectiveness. For this purpose, data were obtained by using qualitative research methods. The research was conducted from qualitative research patterns in the phenomenology pattern. In the 2017-2018 academic year, an easily accessible sampling method was used in the research conducted at a State University in Istanbul. In this study, ten students were interviewed by using semi-structured interview forms and data were obtained within the limitations of these Interview Questions. In the semi-structured interview form, questions were applied as pilot practice with the participation of two students and the understanding of the questions was tested. The data collected was analyzed by content analysis and the students ' perceptions about activity based learning were determined. As a result of the analyses, it was determined that the learning approach with an activity-based approach affects the thoughts of teacher candidates in a positive way. Based on the findings obtained, it can be said that activity-based learning in Science and Technology Teaching increases the effectiveness of teaching.
\end{abstract}

Keywords: Activity Based Learning, Science and Technology Teaching Course, Teacher Candidates

To Cite This Article: Yeşilyurt, M., Erol, M. (2019). Student Opınıons on Effıcacy-Based Learnıng Approach in Scıence and Technology Teachıng: A Phenomenologıcal Study. Journal of Primary Education, 1(1), 40-47.

\footnotetext{
* This study was presented as an oral presentation at the International Basic Education Congress (UTEK).

${ }^{1}$ Yıldız Technical University, Department of Primary Education, Istanbul, Turkey, afra65@yahoo.com

${ }^{2}$ Yıldız Technical University, Department of Primary Education, Istanbul, Turkey, merol@yildiz.edu.tr
} 


\section{Introduction}

In this paper, we will discuss the relationship between the learning process and the learning process. In this approach, students can be guided by guidance teachers, who are in their own interests, to do their desired activities. In this way, it is easier for students to develop their reasoning, creative thinking and problem solving skills (Batdı, 2014).

Activity based learning is used to improve students ' living learning, active participation in the process, and collaboration. Activity-based learning (Biazak, Marley and Levin, 2010), which advocates that students should learn as a result of interaction with their environment, is used in educational settings to develop their own learning strategies, to link the concepts and to provide lasting learning (Mert Cüce, 2012). With the arrangements made in recent years, constructivist education understanding has been adopted. This situation created the necessity to use Activity-Based Learning in teaching environments.

New approaches to learning emphasize the need for students to be more active in learning environments and include some criteria that include environments where teachers can guide their students and provide opportunities (Chickering and Gson 1999, cited in Ebret, 2015).

- Ensuring student-teacher communication

- Improving inter-student cooperation

- Active participation of students in learning environments. On-time feedback to students

- Taking into account the importance of time in a task

- Determination of high-level targets.

- Respect individual differences and different ways of solutions.

The criteria listed above focus on students ' need to be active and learn to learn. Activity based learning is supported by research to minimize these problems.

Research on Activity Based Learning has shown that students ' social and cognitive development is increasing when they engage in activities. Because Activity Based Learning is appropriate for students ' learning by doing and living. This increases the effectiveness of learning. As a matter of fact, the effect of the Activity-Based Learning Approach on academic achievement in the study of activity-based learning method has been shown to contribute to the increase in academic achievement by positively affecting the students 'role of teaching, students' performance in the learning process, and their interest and attitude towards the course.

\subsection{Purpose of the Research}

The aim of this study was to present the ideas of teacher candidates who have been educated in the Department of primary education in order to teach science and technology based on effectiveness. For this purpose, the study sought to answer the following subproblems.

- What are the views of teacher candidates on the effectiveness-based learning approach in Science and Technology Teaching?

- What are the metaphors of the Activity-Based Learning Approach in Science and Technology Teaching experienced by teacher candidates?

- What is the contribution of the Activity-Based Learning approach to professional development in Science and technology teaching that teacher candidates experience? 


\section{Method}

\subsection{Pattern of Research}

Qualitative research is widely used in social sciences, social phenomena, human behavior and the reasons of these behaviors are described as a research intended to reveal in detail (Güler, Halıcıoğlu and Taşkın, 2015). In this research, qualitative research patterns were carried out with phenomenology pattern. Phenomenology explores how people load meanings into experiences they experience as a result of their interaction with their environment (Seggie and Bayyurt, 2015). The purpose of Phenomenological Research; to gain an insight into the Working Group's life experiences and to reveal what makes sense of their lives (Johnson and Christensen, 2014).

The main purpose of the study is to determine the students ' experience in Science and Technology Education and to seek answers to some questions about their experiences. Qualitative research has been preferred in the conduct of the study since it allows face-toface research with participants and is considered to be more appropriate for the purpose of the study.

\subsection{Working Group}

In this study, the criteria for sampling types were carried out by sampling method. Sampling is the study of all situations that meet a set of predefined criteria (Yıldırım and Şimşek, 2016). Research criteria;

- Bachelor of science degree in primary education candidate candidates for the class

- Teacher candidates who have taken lessons in Science and technology teaching course with activity based learning method

Given the above criteria, the working group of the research is classified as the 3rd grade teacher education bachelor's degree. He created teacher candidates studying in his class. A total of 10 teachers, 5 girls and 5 boys, participated in the study. The research was conducted from a State University in Istanbul. Students were included in the study and the activities they designed were presented as an exhibition by the end of the semester. The names of the students who participated in the study were not used in accordance with the ethical rules and instead were stated in the findings of the study using codes.

\subsection{Collection of Data}

In this research, data were obtained by using frequently used interview technique in qualitative research. It is possible to separate qualitative interviews as structured, semistructured and unstructured. In this study, a semi-structured interview form was used as a data gathering tool. The semi-structured interview is a data collection method where the researcher can ask new and different questions about the issues that arise during the interview (Güler, Halıcıoğlu and Taşkın, 2015). Interviewing in this direction; it is necessary to learn about behaviors, situations, emotions or how people express the world around them (Merriam, 2013; Patton, 2014). 


\subsection{Data Analysis}

Data analysis in qualitative research means diversity, creativity and flexibility. Data analysis in each qualitative survey requires a number of different approaches. Therefore, the researcher should develop a data analysis plan for his / her research by taking advantage of the research and the data obtained (Yıldııım and Şimşek, 2016).

Qualitative data analysis can explain the meaning of the obtained data as a way to convey the meaning of the data; to explain what people say, what the researcher saw and read; and to explain the interpretation as a way to reach and make sense of concrete data from concrete data as a process between concrete data and abstract concepts, my incurring and integration (Creswell, 2013; Merriam, 2014).

In this study, the analysis of the data obtained by the semi-structured interview form and the audio recordings were analyzed using content analysis method for the purpose of the research. Content analysis is a qualitative data analysis method used to determine the existence of words, concepts, experiences, characters, or sentences within one or more texts and to quantify them (Seggie and Bayyurt, 2015).

\subsection{Validity and Reliability}

The credibility of the results is considered one of the most important issues of scientific research (Yıldırım and Şimşek, 2016). In this respect, the research is valid and reliable are the two most important issues. In order to ensure the validity and reliability of the research, the following procedures have been performed.

- Prospective teachers were taken into the study on voluntary basis.

- Sampling criteria were preferred from sampling methods for purposes before the study was performed.

- Since the validity of qualitative research is often related to the meanings and results extracted from the data (Güler, Halıcıoğlu and Taşkın, 2015), the research data was also controlled by a different researcher, and similar themes and categories were obtained.

- In order to understand the appropriateness of the questions in the interview form, the first two teacher candidates were pre-applied and both the intelligibility of the questions were measured and the experience before the actual application was obtained.

\section{Findings and Comments}

\subsection{What Are The Views of Teacher Candidates on the Effectiveness-Based Learning Approach in Science and Technology Teaching? Findings Related to Sub-Problem}

Table 1: Views of teacher candidates on the effectiveness-based learning approach in Science and Technology Teaching

1 We learned by doing and living

2 Suitable for contemporary learning theories

3 Ensures the retention of learned information
Teacher candidate, $B$

Teacher candidate, I

Teacher candidate, $\mathrm{E}$ 
Journal of Primary Education, 2019, 1 (1), 40-47

4 Reduces our prejudices against Class

5 It made it easy to transfer the information we learned into our daily lives

6 He helped us love teaching profession

7 Improved communication with friends

8 It made me feel positive about our group activities

9 He showed me that I should respect different views

10 He showed me that I should look at things from Teacher candidate, $O$ different perspectives

Table 1 is examined. It is seen that activity-based science and technology teaching has a positive impact on teacher candidates' views. The candidate of the teacher made us learn by living with the view of "B". Because it was a very good feeling to be involved in the events and discuss the activities we have done. I do not think I will forget this interaction for the rest of my life." In the same way, we have seen many theories and models in teaching principles and methods by stating that the teacher candidate contributes to the development of the science and technology learning approach based on activity, and that today's learning approaches aim to activate the student without making the teacher passive, he said both teacher and textbooks. In this respect, activity-based learning approach is one of the contemporary learning approaches, and education should be used in the life of teaching explained in the form of.

Activity based learning not only contributed to teacher candidates ' learning skills but also to their empathy skills (showing that I should respect different views), their communication skills (enhancing communication with friends), their upper-class skills (reducing our prejudices to class), and so on.

3.2. What are the metaphors of the Activity-Based Learning Approach in Science and Technology Teaching experienced by teacher candidates? Findings Related To Sub-Problem

Table 2: the metaphors of Activity-Based Learning Approach in Science and Technology Teaching experienced by teacher candidates

\begin{tabular}{lll}
\hline 1 & A flower growing as it gets watered & Teacher candidate, $B$ \\
2 & Not giving a fish, but a master who teaches how to fish & Teacher candidate, I \\
3 & The master-apprentice relationship & Teacher candidate, E \\
4 & A cook who cooks & Teacher candidate, M \\
5 & An experiment scientist & Teacher candidate, Y \\
6 & Ant & Teacher candidate, N \\
7 & Worker bee & Teacher candidate, A \\
8 & By asking a boy who wants to learn everything & Teacher candidate, Z \\
9 & Bee & Teacher candidate, S \\
10 & Ants & Teacher candidate, O
\end{tabular}


Table 2 shows that teachers produce metaphors such as "a flower growing as it is irrigated, a master who teaches to fish not to give fish, a master apprentice relationship, a cook who cooks food, a scientist who experiments, Ant, worker bee, a child who wants to learn everything by asking". When the metaphors produced by teacher candidates are examined, they are usually focused on collaborating and providing permanent learning. Teacher candidates compared the most effectiveness-based teaching approach to ants and bees. It is possible to say that the foundation of the activity is due to the fact that teaching can be carried out as a collaborator.

3.3. What is the contribution of Activity-Based Learning Approach to professional development in Science and Technology Teaching? Findings Related To Sub-Problem

All of the prospective teachers think that the contribution of activity-based learning to their professional development is positive. They stated that they could provide classroom-based learning, permanent learning, value-learning, interdisciplinary teaching skills with activity-based learning. The table below gives the answers of the teacher candidates.

Table 3: Contribution of Activity-Based Learning Approach to the Professional Development of Science and Technology Teaching

\begin{tabular}{lll}
\hline $\mathbf{1}$ & I know how to motivate students in class & Teacher candidate, B \\
2 & I can make collaboration easier between students & Teacher candidate, I \\
3 & Students can provide creative thinking skills & Teacher candidate, E \\
4 & I can make the information more permanent. & Teacher candidate, M \\
$\mathbf{5}$ & I can contribute to both learning and playing & Teacher candidate, Y \\
$\mathbf{6}$ & I can make students better value of responsibility & Teacher candidate, N \\
7 & I can minimize individual differences between students & Teacher candidate, A \\
$\mathbf{8}$ & I can use this approach in all classes & Teacher candidate, Z \\
9 & I can make classes more interesting. & Teacher candidate, S \\
10 & Students can improve their problem-solving skills & Teacher candidate, O \\
\hline
\end{tabular}

Table 3 is examined. It is observed that the effectiveness-based learning approach in Science and Technology Teaching experienced by teacher candidates has a positive impact on their professional development. All of the teacher candidates who participated in the study stated that activity-based learning contributed to the professional development and that they could use this approach in all courses when they started their teaching profession. In addition, the teacher candidates mentioned the importance of activity-based learning in the persistence of information. Teacher candidate, $M$, will be able to combine learning with learning knowledge with daily life. With this approach, I think the transfer of information can be easier. In short, this approach can make the information learned more permanent. It has made this situation clear. 


\section{Conclusion and Discussion}

Based on the findings of the research, it is possible to say that the teacher candidates are actively involved in the activities of the teacher candidates and that the information they have learned increases the effectiveness, the ability to learn, and the continuity of the information of the students increases. Findings of the study Kösterelioğlu, Bayar and Akın Kösterelioğlu (2014) show parallels with the results of the looted research. This result supports the results of our work.

Another finding of the study is that teachers produce metaphors such as "a flower growing as it gets wet, a master who teaches to keep fish, not a fish, a master apprentice relationship, a cook, an experimenter, an ant, a worker bee, a child who wants to learn everything by asking." It is possible to say that the metaphors produced as a result of the research increase the permanent learning of the products produced by Labor and cooperatively.

As a result of the research, activity-based learning can be used to increase students 'interest in the course, to decrease Individual Differences in motivation, to collaborate among students, to develop thinking skills, to provide play-based learning, and to increase students' problem-solving skills. In this context, Slavin (2013) stated that in his experimental research, students who have experienced learning based on active learning methods have increased their success in problem solving compared to those who have been taught with traditional understanding. In addition, Küpcü (2012) determined that activity-based teaching approach was an effective approach in the ability to solve the proportional problems of Middle School students in his study entitled the effect of activity-based learning on the success of solving the proportional problems. The findings of these studies show parallelism with the findings of our study.

\section{References}

Batdı, V. (2014). Etkinlik temelli öğrenme yaklaşımının akademik başarıya etkisi (Meta-analitik ve tematik bir çalışma). e-International Journal of Educational Research, 5(3), 39-55.

Biazak, J,. E., Marley, S,. C., \& Levin, J.. L. (2010). Does an activity-based learning strategy improve preschool children's memory for narrative passages? Early Childhood Research Quarterly, 25, 515-526.

Creswell, J.. W. (2013). Araştırma deseni nitel, nicel ve karma yöntem yaklaşımları. (Çev. Ed. Demir, S. B.), Ankara: Eğiten Kitap.

Ebret, A. (2015). Etkinlik temelli matematik öğretiminin 3. Sınıf öğrencilerinin problem çözme becerilerine ve matematiğe ilişkin tutumlarına etkisi, (Yayımlanmamış yüksek lisans tezi), Necmettin Erbakan Üniversitesi, Konya.

Güler, A., Halıcıoğlu, B,. H,. ve Taşğın, S. (2015). Sosyal bilimlerde nitel araştırma. Ankara: Seçkin Yayıncilık.

Johnson, B., ve Christensen, L. (2014). Eğitim araştırmaları (Çev Ed. Demir, S. B). Anklara: Eğiten Kitap.

Kösterelioğlu, İ,. Bayar, A,. ve Akın Kösterelioğlu, M. (2014). Öğretmen eğitiminde etkinlik temelli öğrenme süreci: bir durum araştırması, Turkish Studies, 9(2), 1035-1047.

Küpcü, A., R. (2012). Etkinlik temelli öğretim yaklaşımının ortaokul öğrencilerinin orantısal problemleri çözme başarısına etkisi, Ahi Evran Üniversitesi Kırşehir Eğitim Fakültesi Dergisi (KEFAD), 13(3), 175-206.

Merriam, S,. B. (2014). Nitel araştırma desen ve uygulama için bir rehber. (Çev. Ed. Turan, S.). Nobel Akademi Yayıncllık: Ankara.

Mert Cüce, A., P. (2012). Etkinlik temelli matematik öğretimi yapılan sınıf ortamından yansımalar: aksiyon araştırması. (Yayımlanmamış yüksek lisans tezi), Karadeniz Teknik Üniversitesi, Trabzon.

Seggie, F,. N., ve Bayyurt, Y. (2015). Nitel araştırma. Anı Yayıncılık, Ankara. 
Journal of Primary Education, 2019, 1 (1), 40-47

Slavin, R., E. (2013). Eğitim psikolojisi: kuram ve uygulama. (Yüksel, G. Çev.) Ankara: Nobel Akademik Yayıncılık.

Yıldırım, A., ve Şimşek, H. (2016). Sosyal bilimlerde nitel araştırma yöntemleri, Ankara: Seçkin Yayıncılık. 